\title{
$S$-adenosylhomocysteine treatment of adult female fibroblasts alters X-chromosome inactivation and improves in vitro embryo development after somatic cell nuclear transfer
}

\author{
Byeong-Gyun Jeon, Gianfranco Coppola, Steven D Perrault, Gyu-Jin Rho ${ }^{1}$, Dean H Betts \\ and W Allan King \\ Department of Biomedical Sciences, Ontario Veterinary College, University of Guelph, Guelph, Ontario, Canada \\ N1G 2W1 and ${ }^{1}$ College of Veterinary Medicine, Gyeongsang National University, 900 Gazwa, Jinju 660-701, \\ South Korea
}

Correspondence should be addressed to W A King; Email: waking@uoguelph.ca

\begin{abstract}
The poor outcome of somatic cell nuclear transfer (SCNT) is thought to be a consequence of incomplete reprogramming of the donor cell. The objective of this study was to investigate the effects of treatment with $S$-adenosylhomocysteine (SAH) a DNA demethylation agent, on DNA methylation levels and $\mathrm{X}$-chromosome inactivation status of bovine female fibroblast donor cells and the subsequent impact on developmental potential after SCNT. Compared with non-treated controls, the cells treated with SAH revealed (i) significantly $(P<0.05)$ reduced global DNA methylation, (ii) significantly ( $\sim 1.5$-fold) increased telomerase activity, (iii) diminished distribution signals of methylated histones $\mathrm{H} 3-3 \mathrm{mK} 9$ and $\mathrm{H} 3-3 \mathrm{mK} 27$ on the presumptive inactive $\mathrm{X}$-chromosome (Xi), (iv) alteration in the replication pattern of the $\mathrm{Xi}$, and (v) elevation of transcript levels for X-chromosome linked genes, ANT3, MECP2, XIAP, XIST, and HPRT. SCNT embryos produced with SAH-treated donor cells compared with those derived from untreated donor cells revealed (i) similar cleavage frequencies, (ii) significant elevation in the frequencies of development of cleaved embryos to hatched blastocyst stage, and (iii) 1.5-fold increase in telomerase activity. We concluded that SAH induces global DNA demethylation that partially reactivates the Xi, and that a hypomethylated genome may facilitate the nuclear reprogramming process.

Reproduction (2008) 135 815-828
\end{abstract}

\section{Introduction}

In mammalian cells, $\sim 1-4 \%$ of cytosine nucleotides are modified by the covalent addition of a methyl group to carbon-5 of the cytosine pyrimidine ring, primarily at CpG dinucleotides. This results in the conversion to 5 -methylcytosine and methylation of up to $70 \%$ of the CpG dinucleotides in the genome. These methyl groups covalently bind to the major groove of DNA and effectively inhibit transcription. Gene expression regulation by DNA methylation is proposed as the key mechanism initiating essential events in mammalian embryogenesis ranging from the establishment of imprinted signals in gametes to the unfolding of the developmental pattern in the embryo. Examples of such processes include the genome-wide global reprogramming after fertilization, the repression of transcription of genes clustered on an individual chromosome as is the case with imprinted genes or X-chromosome inactivation $(\mathrm{XCl})$ and up- and down-regulation of individual genes, in a timely and tissue-specific manner (Bird 2002).
A family of DNA methyltransferases (DNMTs), whose co-substrates are DNA and S-adenosylmethionine (SAM), an important methyl donor, generally catalyzes the addition of methyl groups in most transmethylation reactions, which after transfer of the methyl group is converted to $S$-adenosylhomocysteine $(\mathrm{SAH}) . \mathrm{SAH}$, the metabolite of SAM, has much higher affinity for the methyltransferase active site than does its precursor; therefore most cellular methyltransferase is inhibited by the accumulation of intracellular and cellular SAH. Thus, the ratio of cellular SAM and SAH has been frequently used as an indicator of DNA methylation potential (Yi et al. 2000, Caudill et al. 2001, Castro et al. 2005).

The importance of DNA methylation-mediated developmental regulation is particularly evident after somatic cell nuclear transfer (SCNT), a process that relies on the ability of a mature enucleated oocyte to reprogram a differentiated somatic genome to enable the re-establishment of totipotency and the postfertilization developmental program. While this technique has been successfully applied to a number of species (Vajta 2007), the success rate in terms of the 
number of live clones per manipulation remains low $(1-5 \%)$ along with a high incidence of perinatal mortality and unexplained congenital malformations (reviewed by Han et al. 2003).

One of the proposed causes for the inefficiencies in the SCNT process is the inability to completely 'dedifferentiate' and reprogram the differentiated somatic donor cell. Under normal reproductive circumstances, upon fertilization, the paternal genome from sperm is demethylated by an active mechanism prior to DNA synthesis. Concomitantly, the maternal genome of the oocyte is demethylated by a passive mechanism that depends on DNA replication and then, in the embryo, DNA is de novo re-methylated by the blastocyst stage (Morgan et al. 2005). As differentiation progresses, the cells tend to establish and maintain characteristic constituent protein profiles that result from specific patterns of gene expression acquired during development and regulated, in part, by high levels of DNA methylation and histone modifications that bind to chromatin (Bird 2002, Morgan et al. 2005). However, it has been reported that unlike the maternal genome in the fertilized oocyte, the differentiated SCNT donor cell undergoes a reduced or incomplete passive demethylation after injection into the oocytes with a subsequent de novo methylation event occurring at an earlier stage compared with non-SCNT embryos (Bourc'his et al. 2001, Kang et al. 2001). The abnormal reprogramming of DNA methylation in SCNT embryos could lead to the abnormal expression of genes and result in the failed or confused reactivation of the genes that are essential for proper embryonic development. Indeed, comparison of embryos and fetuses produced by SCNT with those produced by fertilization has revealed deviations in the developmental chronology of expression of telomerase (Betts et al. 2001), an enzyme necessary for reestablishing telomere length in somatic cells, and in the levels of a select panel of genes associated with growth, differentiation, and metabolism (Herath et al. 2006, Li et al. 2006), including several located on the X-chromosome (Wrenzycki et al. 2002).

Telomerase, an enzyme whose expression is for the most part undetectable in most differentiated somatic cells is also associated with DNA methylation (Gonzalo et al. 2006) and modification of chromatin structure by nucleosomal histones (Blasco 2003, Gonzalo et al. 2006). Telomerase up-regulation has been used as an index of transcriptional activity in partially hypomethylated cells (Renaud et al. 2007) and the reappearance of telomerase expression in cloned embryos (Betts et al. 2001) has been used as a marker of reprogramming efficiency. Among clones, the status of telomere reconstruction varies widely from complete rebuilding to significantly shorter or even longer lengths than agematched controls (Lanza et al. 2000, Betts et al. 2001). These variations presumably reflect the ability of the recipient oocyte to effectively initiate reprogramming of telomerase expression.
Similarly, some SCNT embryos and offspring have been shown to exhibit aberrations in XCl (Xue et al. 2002, Nolen et al. 2005), a process required to balance the gene dosage differences resulting from the different number of X-chromosomes in females and males. During early embryogenesis, this process is induced by $X$-chromosome-inactive-specific transcript (XIST) RNA coating one of the two X-chromosomes in every cell of a female embryo (Brockdroff 2002, Heard 2004, Chang et al. 2006). Immediately after XIST RNA coating begins, the inactivated $\mathrm{X}$-chromosome $(\mathrm{Xi})$ undergoes various chromatin modifications such as loss of methylation of $\mathrm{H} 3$ lysine $4(\mathrm{H} 3-\mathrm{K} 4)$, methylation of histone $\mathrm{H} 3$ lysine 9 (H3-K9), and methylation of $\mathrm{H} 3$ lysine $27(\mathrm{H} 3-\mathrm{K} 27)$, and these changes lead to transcriptional silencing (Peters et al. 2002, Plath et al. 2003, Chadwick \& Willard 2004) and late replication of one of the X-chromosomes (Keohane et al. 1999). However, histone modification such as H3-K27 methylation is not sufficient for silencing of the X-chromosome (Plath et al. 2003). Hence, the inactive state is synergistically maintained through other chromatin modifications such as hypoacetylation at histone $\mathrm{H} 4$, macroH2A recruitment, and DNA methylation (Csankovszki et al. 2001). Nonetheless, the functional links between methylated DNA and histones on the X-chromosome are extremely stable and are maintained throughout all subsequent cell divisions and life (Avner \& Heard 2001). On the other hand, when $\mathrm{CpG}$ dinucleotides of the $\mathrm{Xi}$ are demethylated, the fate of $\mathrm{H} 3-3 \mathrm{mK} 9$ and $\mathrm{H} 3-3 \mathrm{mK} 27$ distribution, replication timing, and the levels of $\mathrm{X}$-linked genes expression on the hypomethylated $\mathrm{Xi}$ chromosome remain unclear.

To further explore the mechanisms involved in dedifferentiation, we have used telomerase activity and $X$-inactivation as markers for reprogramming with the following objectives: (1) to investigate the effects of altered DNA methylation on telomerase activity; (2) to analyze the pattern of $\mathrm{XCl}$ by analyzing the distribution of inactivated $\mathrm{X}$-chromosome-specific histones $\mathrm{H} 3-3 \mathrm{mK} 9$ and $\mathrm{H} 3-$ $3 \mathrm{mK} 27$, the replication timing of the inactivated $\mathrm{X}$-chromosome, and by measuring the transcript levels of various X-linked genes by real-time RT-PCR in hypomethylated female fibroblast cells treated with $\mathrm{SAH}$; and (3) to determine the impact of SAH pretreatment of the SCNT donor cell on the in vitro developmental potential and telomerase activity of the resultant SCNT embryos.

\section{Results}

\section{Global DNA methylation levels in SAH-treated cells}

The amount of global DNA methylation was determined using relative fluorescence intensity (RFI) of 5-methylcytosine immunostaining emitted from the nuclei of control and SAH-treated cells. Fluorescence intensity of the non-treated control cells was considered as $100 \%$ for comparison with the treatment groups. The 
nuclear fluorescence of SAH-treated cells was apparently reduced compared with control cells (Fig. 1A-F). RFI measurements demonstrated significantly $(P<0.05)$ reduced levels of methylated DNA at all concentrations tested with reduced $\mathrm{RFI}$ evident with increasing SAH concentrations (Fig. 1G). RFI values of cells treated with

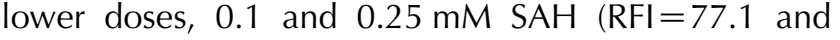
$56.0 \%$ respectively), were significantly $(P<0.05)$ different from controls and each other, whereas higher doses, 0.5, 1.0, and $2.0 \mathrm{mM} \mathrm{SAH} \quad(\mathrm{RFI}=39.9$, 38.9 and $39.5 \%$ respectively), were significantly $(P<0.05)$ different from controls and lower doses but not significantly $(P>0.05)$ different from each other (Fig. 1G).

\section{Telomerase activity levels in SAH-treated cells}

To analyze the impact of an altered DNA methylation state on gene expression levels, telomerase activity was assessed as an indicator of altered gene expression since previously it has been shown to be modulated by the
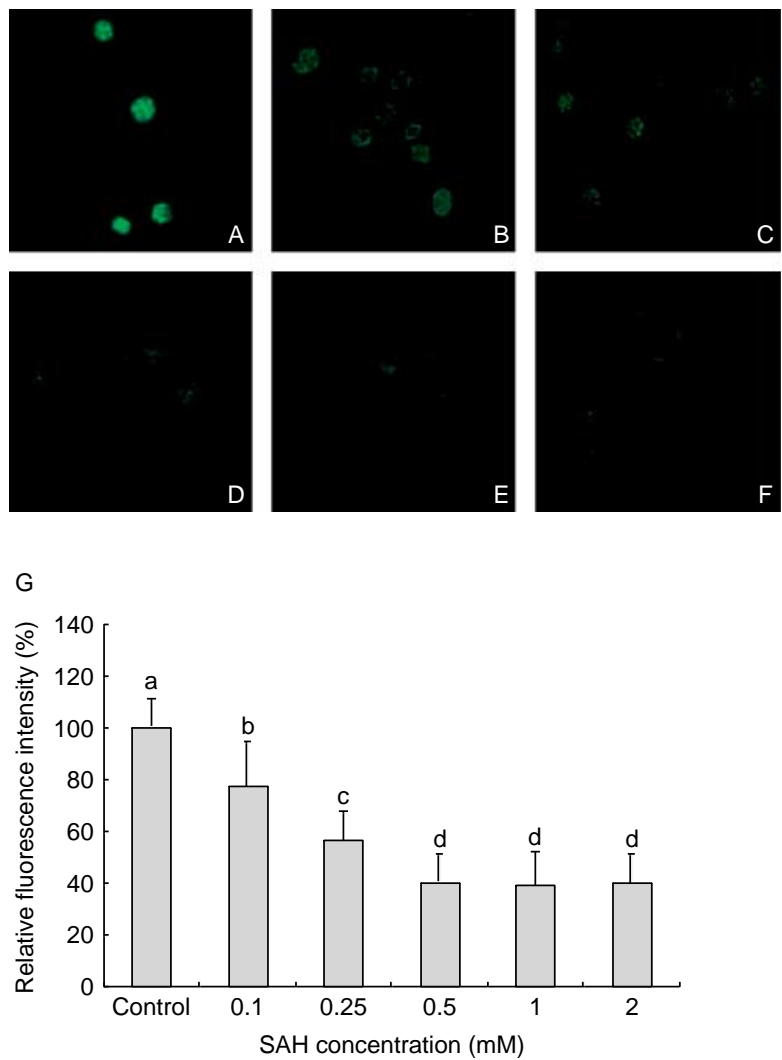

Figure $1 \mathrm{Imm}$ mofluorescence staining with antibody against 5-methylcytosine detected by FITC-conjugated secondary antibody (green) in the nuclei of cells treated with (A) control, (B) $0.1 \mathrm{mM}$, (C) $0.25 \mathrm{mM}$, (D) $0.5 \mathrm{mM}$, (E) $1.0 \mathrm{mM}$, (F) and $2.0 \mathrm{mM} \mathrm{SAH}$. (G) Relative fluorescence intensity (RFI) of 5-methylcytosine immunostaining emitted from the nuclei of cells treated with each concentration of SAH. The RFI of the control cells was considered as $100 \%$ for comparison with other treatments. Bars with different letters are significantly $(P<0.05)$ different.
DNA methylation status of the catalytic subunit (telomerase reverse transcriptase, TERT) promoter (Guilleret $\&$ Benhattar 2003). The real-time quantitative telomeric repeat amplification protocol (RQ-TRAP) assay was applied to control and SAH-treated cells. Telomerase activity in the control cells was considered as $100 \%$ for comparison with other treatment groups. Relative telomerase activity (RTA) in $0.25,0.5,1.0$, and $2.0 \mathrm{mM}$ SAH-treated cells was significantly higher $(P<0.05)$ than those in control and $0.1 \mathrm{mM}$ SAH groups (Fig. 2). Furthermore, RTA was significantly $(P<0.05)$ elevated with treatments of increasing $\mathrm{SAH}$ concentrations up to $1.0 \mathrm{mM}$, reaching levels over $150 \%$ that of controls. RTA in $2.0 \mathrm{mM} \mathrm{SAH}$-treated cells was significantly higher $(P<0.05)$ than those in control and $0.1 \mathrm{mM} \mathrm{SAH}$-treated cells; however, it was significantly lower $(P<0.05)$ than those in 0.5 and $1.0 \mathrm{mM} \mathrm{SAH}$ concentrations (Fig. 2).

\section{Localization of histones H3-3mK9 and H3-3mK27 on the $X$-chromosomes}

The localization of trimethylated histones $\mathrm{H} 3$ lysine 9 and 27 ( $\mathrm{H} 3-3 \mathrm{mK} 9$ and $\mathrm{H} 3-3 \mathrm{mK} 27)$ on the metaphase spreads have been used as markers of the inactivated X-chromosome (Chadwick \& Willard 2004). Since treatment of fibroblasts with $1.0 \mathrm{mMSAH}$ resulted in the lowest DNA methylation levels and the highest telomerase activity, only metaphase chromosomes from the control and $1.0 \mathrm{mM} \mathrm{SAH}$-treated cells were immunostained with $\mathrm{H} 3-3 \mathrm{mK} 9$ and $\mathrm{H} 3-3 \mathrm{mK} 27$ antibodies and evaluated for the presence or absence of $\mathrm{H} 3-3 \mathrm{mK} 9$ and $\mathrm{H} 3-3 \mathrm{mK} 27$ staining on both X-chromosomes of each metaphase spread analyzed (Fig. 3). In all 80 metaphase spreads from control female cells, intense labeling of both $\mathrm{H} 3-3 \mathrm{mK} 9$ and $\mathrm{H} 3-$ $3 \mathrm{mK} 27$ antibodies was detected on one X-chromosome (the presumptive inactive, $\mathrm{Xi}$ chromosome), but was not detected on the other (the presumptive active, $\mathrm{Xa}$ chromosome; Fig. 3B and C). However, in the metaphase spreads of cells treated with $1.0 \mathrm{mM} \mathrm{SAH}$, the $\mathrm{H} 3-3 \mathrm{mK} 9$

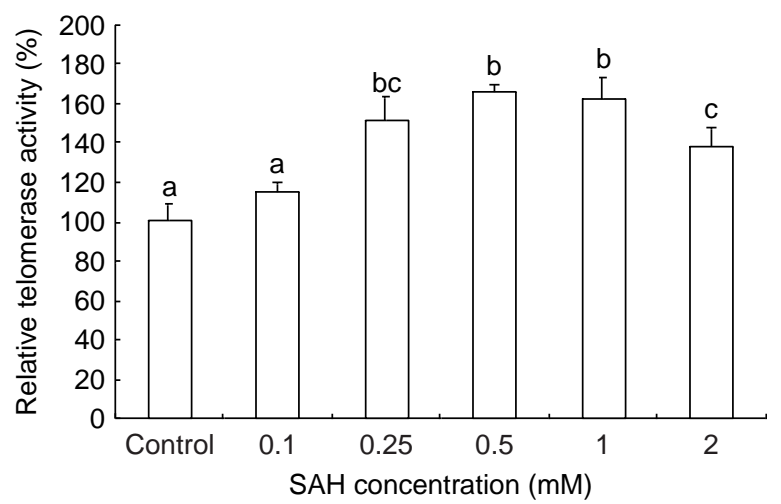

Figure 2 Relative telomerase activity (RTA) in the nuclei of cells treated with increasing concentration of SAH. RTA of the non-treated control cells was considered as $100 \%$ for comparison with SAH treatments. Bars with different letters are significantly $(P<0.05)$ different. 

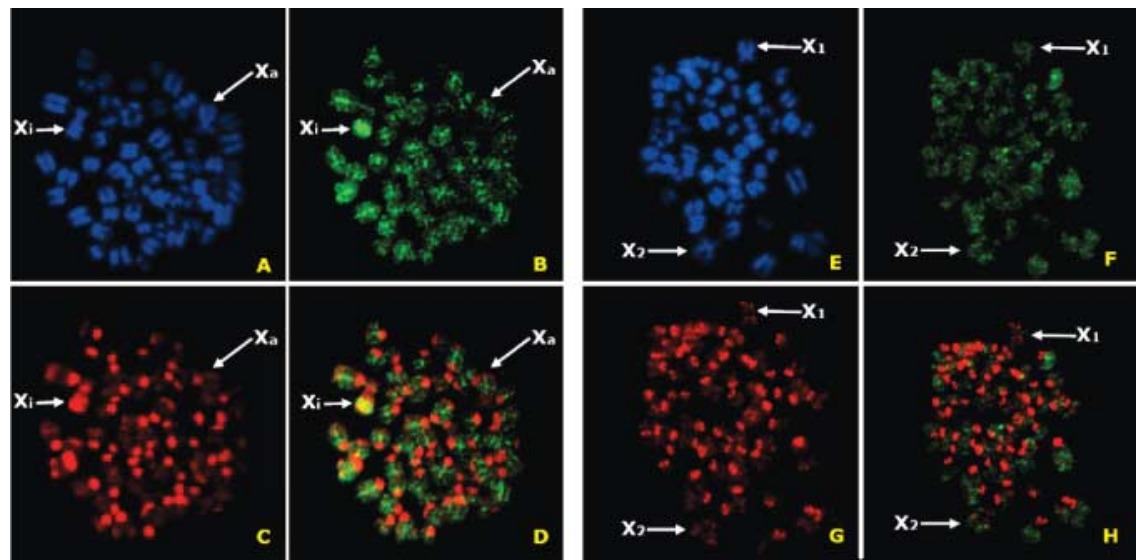

Figure 3 Distribution of $\mathrm{H} 3-3 \mathrm{mK} 9$ and $\mathrm{H} 3-3 \mathrm{mK} 27$ on the metaphase spread derived from (A-D) control and (E-H) $1.0 \mathrm{mM}$ SAH-treated cells. Simultaneous double staining with antibodies against $\mathrm{H} 3-3 \mathrm{mK} 27$ was detected by FITC-conjugated secondary antibody (B and F; green) and H3-3mK9 by Alexa 594-coupled secondary antibody (C and G; red). DNA was counterstained with DAPI (A and E) and the merged image (D and $H$ ) consists of H3-3mK27 (green) and H3-3mK9 (red). Distribution of both $\mathrm{H} 3-3 \mathrm{mK} 9$ and $\mathrm{H} 3-3 \mathrm{mK} 27$ were seen on the inactivated X-chromosome (Xi), and no distribution was detected on the activated X-chromosome (a) of control cell (B and C). But distribution of both H3-3mK9 and H3-3mK27 staining were not typically detected on both X-chromosomes (X1 and X2) of SAH-treated cells ( $F$ and $\mathrm{G})$.

antibody labeling was detected on one X-chromosome in only $59.5 \%(52 / 74)$ of the metaphase spreads analyzed, while in $40.5 \%(22 / 74)$ of the cells no labeling of either $\mathrm{X}$-chromosome was seen (Fig. 3G). Furthermore, the majority $(82.4 \%$; $61 / 74)$ of the cells showed no labeling with H3-3mK27 antibody, while only $17.6 \%$ (13/74) of the cells showed labeling over one X-chromosome (Fig. 3F). Combined, the pattern of X-chromosome labeling with antibodies on SAH-treated cells was significantly $(P<0.05)$ reduced compared with those of control cells with a frequency of detection of H3-3mK27 significantly $(P<0.05)$ lower than that for $\mathrm{H} 3-3 \mathrm{mK} 9$ on SAH-treated cells (Table 1). However, for those treated cells showing incorporation of both antibodies, the pattern was similar to the untreated controls (Fig. 3B and C).

\section{Replication timing of the $X$-chromosomes in SAH-treated cells}

Acridine orange, a fluorescent dye, intercalates in the spirals of the DNA strand; however, bromodeoxyuridine
(BrdU), which is a structural antagonist of thymidine, interferes with the fluorescence emitted by the dye and indicates BrdU-rich (late replicating) regions of DNA. $\mathrm{BrdU}$ incorporation patterns on the $\mathrm{X}$-chromosomes were classified as follows: zero (Z), without incorporation on either the short (p) or long (q) arm (Fig. 4A); low (L), one or few bands of $\mathrm{BrdU}$ incorporation on the $\mathrm{q}$ arm and none on the p arm; medium $(M)$, several $(>2)$ reverse band acridine orange (RBA) bands on the $q$ arm and few/none on the $p$ arm; and high $(H)$, numerous (5-10) bands on both the $q$ and $p$ arms (Fig. 4B). In the normal situation, a metaphase spread showing a pattern that was $\mathrm{HZ}$ was considered to indicate late replication of the inactivated or presumed inactivated X-chromosome. Reactivation of the inactivated $\mathrm{X}$-chromosome would exhibit a pattern classified as ZZ indicating that both $X$-chromosomes replicate early in S-phase, while $M Z$ and LZ indicate heterogeneous or partial late replication of one of the $\mathrm{X}$-chromosomes. The metaphase spreads of control cells exhibited a predominantly late replication pattern for one of the two X-chromosomes characterized by an incorporation pattern

Table 1 Localization of histones $\mathrm{H} 3-3 \mathrm{mK} 9$ and $\mathrm{H} 3-3 \mathrm{mK} 27$ on the X-chromosomes of metaphase spreads derived from control and $1.0 \mathrm{mM}$ $S$-adenosylhomocysteine $(\mathrm{SAH})$-treated female bovine fibroblasts.

No. $(\%)$ metaphase spreads containing one or no X-chromosome positive for trimethylated histone $\mathrm{H} 3$

\begin{tabular}{|c|c|c|c|c|c|}
\hline \multirow[b]{3}{*}{ Treatment } & \multirow{3}{*}{$\begin{array}{l}\text { No. of metaphase } \\
\text { spreads analyzed }\end{array}$} & \\
\hline & & \multicolumn{2}{|c|}{$\mathrm{H} 3-3 \mathrm{mK} 9$} & \multicolumn{2}{|c|}{$\mathrm{H} 3-3 \mathrm{mK} 27$} \\
\hline & & 1 Positive & 0 Positive & 1 Positive & 0 Positive \\
\hline Control & 80 & $80(100)^{*}$ & $0(0)^{*}$ & $80(100)^{*}$ & $0(0)^{*}$ \\
\hline $\mathrm{SAH}$ & 74 & $52(59.5)^{\dagger}$ & $22(40.5)^{t, \neq}$ & $13(17.6)^{\dagger}$ & $61(82.4)^{t, \S}$ \\
\hline
\end{tabular}

Different superscripts within columns ${ }^{*,+}$ and row $^{\ddagger, \S}$ indicate significant differences $(P<0.05)$. 

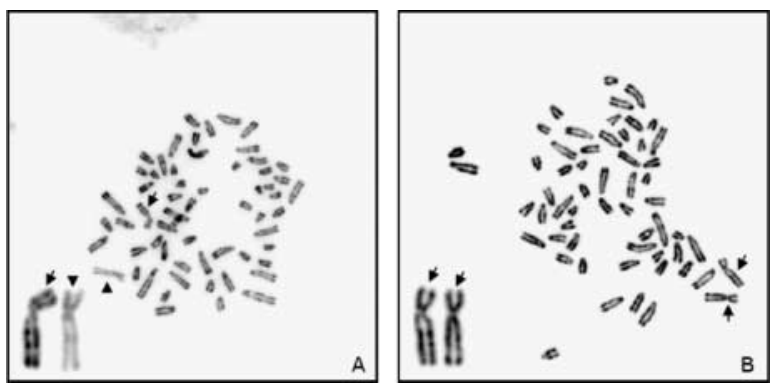

Figure 4 RBA banding replication on the X-chromosomes of cells treated with $S$-adenosylhomocysteine $(\mathrm{SAH})$. (A) A representative example of a chromosome spread from a control cell showing no BrdU incorporation (early replicated) on the activated X-chromosome (arrows) and high incorporation (late replicated) on the inactivated $\mathrm{X}$ chromosome (arrowheads). (B) Example of a spread from $1.0 \mathrm{mM} \mathrm{SAH}$ treated cell showing no BrdU incorporation (early replicated) on both of X-chromosome (arrows). However, the pattern of incorporation was slightly different between both X-chromosomes.

that was $\mathrm{HZ}, \mathrm{MZ}, \mathrm{LZ}$, and $\mathrm{ZZ}$ in $68.4 \%$ (78/114), $28.1 \%$ $(32 / 114), 1.8 \%(2 / 114)$, and $1.8 \%(2 / 114)$ of cells respectively. However, the metaphase spreads from the SAH-treated cells primarily exhibited a heterogeneous or partial late replication pattern as follows: $\mathrm{HZ} 36.7 \%$ (87/237), MZ 20.7\% (49/237), LZ 25.7\% (61/237), ZZ and $16.9 \%(40 / 237)$ (Table 2). The frequencies of X-chromosomes with $\mathrm{HZ}, \mathrm{LZ}, \mathrm{ZZ}$ BrdU incorporation pattern in the SAH-treated cells was significantly $(P<0.05)$ different than those in the control cells. Those SAH-treated cells with X-chromosomes showing a late replication pattern $(\mathrm{HZ})$ were indistinguishable from controls.

\section{Transcript levels of $X$-chromosome-linked genes in SAH-treated cells}

Quantitative real-time RT-PCR was used for measuring various X-linked transcripts ( ANT3, HPRT, MECP2, RPS4X, $X I A P, X I S T$, and $Z F X)$ and autosomal transcripts, ACTB and $\mathrm{H} 2 \mathrm{~A}$, in control and $1.0 \mathrm{mM}$ SAH-treated cells (Fig. 5). Transcript levels of the autosomal controls, $A C T B$ and $H 2 A$, did not differ significantly $(P>0.05)$ between the non-treated and $\mathrm{SAH}$-treated fibroblasts. Although the transcript levels of $X$-linked genes including ANT3, HPRT, $M E C P 2, X I A P$, and XIST in the SAH-treated samples tended to be slightly increased, $\sim 1.5$-fold in relation to controls, there was no significant $(P>0.05)$ difference except for $H P R T$, which was significantly higher $(P<0.05)$ in the $\mathrm{SAH}$-treated samples compared with the controls. The transcript levels for RPS4X and ZFX in the SAH samples were not altered compared with controls $(P>0.05)$.

\section{In vitro development of SCNT embryos derived from $S A H$-treated cells}

The frequencies of fusion, cleavage to two-cell stage, and development to blastocyst stage in the SCNT embryos derived from the nuclear transfer of control and $1.0 \mathrm{mM}$ SAH-treated cells are summarized in Table 3. No significant $(P<0.05)$ differences in the fusion and cleavage incidences were observed between the SCNT embryos derived from the control and $\mathrm{SAH}$-treated cells (93.8\% vs $93.9 \%$ and $90.5 \%$ vs $92.2 \%$ respectively). However, after culture, the percentages of embryos that reached the blastocyst and hatched blastocyst stages in the SCNT embryos derived from the SAH-treated cells were significantly $(P<0.05)$ higher than those reconstructed with the control cells (33.8 and $24.9 \%$ compared with 26.1 and $15.3 \%$ respectively). There were no significant differences in the mean number of total and ICM cells in the SCNT embryos derived from either control or SAH-treated cells $(178.3 \pm 35.1$ and $41.4 \pm 8.5$ and $197.1 \pm 26.5$ and $43 \pm 7.7$ respectively).

\section{Telomerase activity levels in SCNT embryos derived from SAH-treated cells}

To evaluate the extent of nuclear reprogramming in the SCNT embryos, telomerase activity was investigated at the blastocyst stage of SCNT embryos derived from the SAHtreated and non-treated cells on day 9 by the RQ-TRAP method. Telomerase activity in the SCNT embryos derived from the control cells was considered as $100 \%$ for comparison with SCNT embryos derived from the SAH-treated cells. RTA in the SCNT embryos derived from the SAH-treated cells was significantly $(P<0.05)$ increased, $\sim 1.5$-fold higher in relation to controls (Fig. 6).

Table 2 Degree of bromodeoxyuridine (BrdU) incorporation on the X-chromosomes of metaphase spreads derived from control and $1.0 \mathrm{mM}$ $S$-adenosylhomocysteine (SAH)-treated cells.

No. $(\%)$ of metaphase spreads with varying levels of BrdU incorporation on the X-chromosomes

\begin{tabular}{lccccc} 
& $\begin{array}{c}\text { No. of metaphase } \\
\text { sreatment }\end{array}$ & High, Zero $(\mathrm{HZ})$ & Medium, Zero (MZ) & Low, Zero (LZ) & Zero, Zero (ZZ) \\
\hline Sontrol & 114 & $78(68.4)^{*}$ & $32(28.1)^{*}$ & $2(1.8)^{*}$ & $2(1.8)^{*}$ \\
SAH & 237 & $87(36.7)^{+}$ & $49(20.7)^{*}$ & $51(25.7)^{+}$ & $40(16.9)^{+}$ \\
\hline
\end{tabular}

Different superscripts*, ${ }^{\dagger}$ within columns indicate significant differences $(P<0.05)$. Zero $(Z)$, no BrdU incorporation on either the short $(p)$ or long $(q)$ $\mathrm{arm}$. Low $(\mathrm{L})$, one or few bands of BrdU incorporation on the $q$ arm and none on the $\mathrm{p}$ arm. Medium $(\mathrm{M})$, several bands of BrdU incorporation on the $q$ arm and a few on the $p$ arm. High $(H)$, numerous bands of BrdU incorporation on both the $q$ and $p$ arms. 

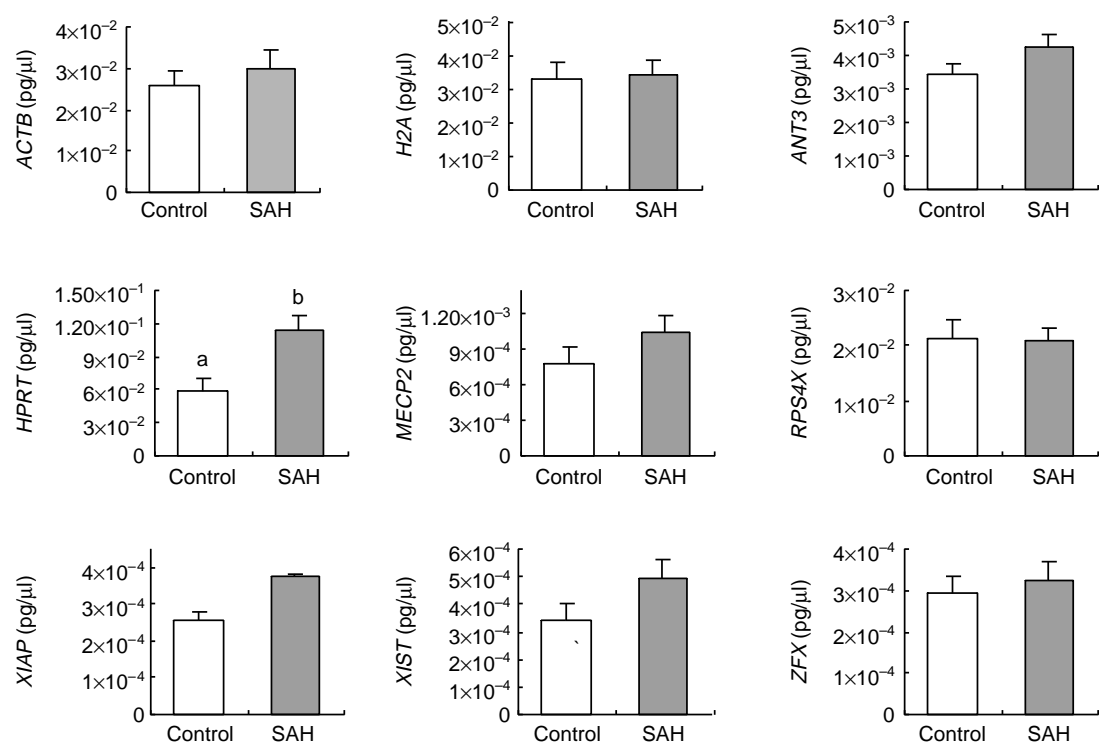
Figure 5 Transcript levels of X-linked genes by real-time RT-PCR in the control and $1.0 \mathrm{mM}$ $\mathrm{SAH}$-treated cells. Bars with different letters are significantly $(P<0.05)$ different.

\section{Discussion}

Mounting evidence strongly suggests that the developmental failures and abnormalities of SCNT embryos may be due to incomplete epigenetic reprogramming of the differentiated donor somatic genome (reviewed by Morgan et al. 2005). Cloned embryos closely resemble donor cells in their overall genomic methylation status generally being hypermethylated compared with their in vitro or in vivo fertilized counterparts (Bourc'his et al. 2001, Dean et al. 2001, Kang et al. 2001). Our data have demonstrated that SAH treatment of fibroblasts induces global DNA demethylation, elevates telomerase activity, and partially reactivates the inactivated $\mathrm{X}$-chromosome. Moreover, the use of SAH-induced hypomethylated donor somatic cells increases the developmental potential for SCNT embryos that also exhibit greater telomerase activity levels, indicative of an enhanced dedifferentiation (nuclear reprogramming) of the transplanted somatic cell genome.

\section{Global demethylation}

DNA demethylating drugs can be grouped into two classes according to their mode of action. Nucleoside analogs, such as 5-aza-2'-deoxycytidine (5-aza-dC), are incorporated into the DNA of replicating cells, where they result in the formation of covalent complexes with DNMTs (Christman 2002). On the other hand, nonnucleoside compounds, such as SAH (an analog of the universal methyl donor metabolite SAM), inhibit DNMT enzymatic activity without being incorporated into the DNA (De Cabo et al. 1994). Although 5-aza-dC is cytotoxic causing either cell cycle arrest (senescence) or apoptosis, especially at high doses, SAH does not appear to elicit any cytotoxic effects (De Cabo et al. 1994, Nieto et al. 2004). This attribute was the primary reason for choosing SAH treatment to reduce DNA methylation levels in fibroblast donor cells in this study.

Estimation of the RFI of 5-methylcytosine immunostaining emitted from the nuclei is one of several, albeit somewhat insensitive, ways that has been used, in a variety of contexts, to estimate global DNA methylation status of cells and embryos (Enright et al. 2005). We used this approach to qualitatively determine whether SAH treatment administered over two cell culture passages has the capacity to alter genome-wide methylation levels. Cellular or intracellular high SAH concentration or decreased SAM/SAH ratio induces global hypomethylation of DNA, RNA, proteins, and phospholipids of cells

Table 3 In vitro development of somatic cell nuclear transfer (SCNT) embryos derived from control and $1.0 \mathrm{mM}$ S-adenosylhomocysteine (SAH)-treated donor cells.

\begin{tabular}{|c|c|c|c|c|c|}
\hline \multirow[b]{2}{*}{ Treatment } & \multirow[b]{2}{*}{ No. of oocyte fused } & \multicolumn{4}{|c|}{ No. (\%) of embryos developed to } \\
\hline & & 2-cell & Blast & $\mathrm{H}$-blast ${ }^{\mathrm{a}}$ & $\begin{array}{l}\text { Total cell no. } \\
\text { (ICM cell no.) }\end{array}$ \\
\hline Control & 883/941 (93.8) & $698 / 771(90.5)$ & 201/771 (26.1)* & $118 / 771(15.3)^{*}$ & $178.3 \pm 35.1(41.4 \pm 8.5$ \\
\hline $1.0 \mathrm{mM}$ SAH & $828 / 884(93.7)$ & $725 / 786(92.2)$ & $266 / 786(33.8)^{\dagger}$ & $196 / 786(24.9)^{\dagger}$ & $197.1 \pm 26.5(43.4 \pm 7.7)$ \\
\hline
\end{tabular}

Percentages with different superscripts within columns indicate significant $(P<0.05)$ differences.

aHatching blastocysts. 


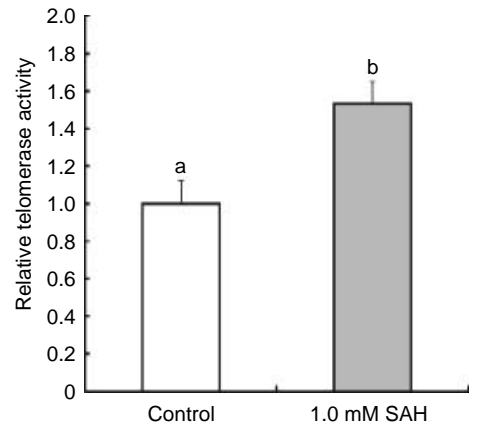

Figure 6 Relative telomerase activity (RTA) of SCNT embryos derived from control and $1.0 \mathrm{mM}$ SAH-treated donor cells. The RTA of SCNT embryos derived from the control donor cells was considered as $100 \%$ for comparison with SAH-treated donor cells. Bars with different letters are significantly $(P<0.05)$ different.

and tissues, since high-affinity binding of SAH to the active site of cellular methyltransferases results in product inhibition of the enzyme (Yi et al. 2000, Caudill et al. 2001, Castro et al. 2005). Here, we have detected high levels of DNA demethylation in fibroblasts subsequent to daily treatment with $\mathrm{SAH}$ (up to $1.0 \mathrm{mM}$ $\mathrm{SAH})$ over two cell passages ( $\sim 10$ days). The level of DNA demethylation appeared to plateau at an RFI of about $40 \%$ of controls with treatment of $0.5 \mathrm{mM} \mathrm{SAH}$ and higher, suggesting a threshold concentration for $\mathrm{SAH}$ treatment. Similar observations have been made with other demethylating agents such as 5-aza-dC in which higher concentrations limit demethylation possibly due to cytotoxicity (Enright et al. 2005). 5-Aza-dC induces a dose-dependent reduction in global DNA methylation levels, but also inhibits cell proliferation with elevated chromosomal abnormalities and apoptosis levels at high (>0.5 $\mu \mathrm{M})$ concentrations (Mohana Kumar et al. 2006). Alternatively, it has been reported in HepG2 cells that a reduction in global DNA methylation of $\sim 30 \%$ was induced by $1 \mathrm{mM} \mathrm{SAH}$ for $24 \mathrm{~h}$ (Hermes et al. 2004) and $1 \mathrm{mM}$ SAH for 3 days in mouse fibroblasts without cytotoxicity (Nieto et al. 2004). This may be due to the short exposure to $\mathrm{SAH}$ in those studies, as $\mathrm{SAH}$ is rapidly oxidized to the sulfoxide in alkaline solutions (De Cabo et al. 1994). We have also observed that 5-azacytidinetreated fibroblasts arrested at G1/S-phase of cell cycle, while SAH treatment did not appear to have any effect on cell proliferation (data not shown).

\section{Effect of SAH treatment on telomerase activity}

Telomerase activity levels were assessed in the SAHtreated fibroblast donor cells as a marker for gene activation by global DNA demethylation. Telomerase activity is tightly regulated by the expression of TERT and telomerase RNA component (TERC), two main subunits of the telomerase holoenzyme. TERT seems to be the rate-limiting factor for telomerase activity with hTERT expression apparently regulated by the methylation status of its promoter (Cong et al. 1999, Shin et al. 2003). Although there have been some discrepancies (Guilleret \& Benhattar 2003), generally CpG island methylation of the hTERT promoter is associated with low/no telomerase activity (Bechter et al. 2002, Shin et al. 2003). Treatment of human cell lines with 5-aza-dC induces expression of hTERT, suggesting a potential role for DNA methylation contributing to hTERT repression in some cells (Dessain et al. 2000). Recently, it has been reported that lack of DNMTs results in increased telomerase activity and subtelomeric DNA hypomethylation associated with elongated telomeres in DNMTdeficient mouse embryonic stem cells (Gonzalo et al. 2006). In addition, alterations in histone tails of chromosome have been demonstrated to negatively regulate telomere length, and loss of these heterochromatic marks such as di- and trimethylation of $\mathrm{H} 3-\mathrm{K} 9$ leads to telomere elongation in mouse cells (Garcia-Cao et al. 2004), suggesting that DNA modification of compacted chromatin status and DNA methylation itself are fundamental factors for negative control of telomerase activity and/or its access to telomeres in mammalian cells. In our studies, telomerase was increased in adult bovine fibroblasts traditionally known to be telomerase negative (Betts et al. 2001). Our detection of telomerase activity in non-treated control fibroblasts may be due to the greater sensitivity of using the real-time RQ-TRAP method of telomerase detection (Perrault et al. 2005). Recently, telomerase has been found, in normal human somatic cells, to maintain telomere structure as a postulated means for chromosomal stability (Masutomi et al. 2003). Increased telomerase activity induced by $\mathrm{SAH}$ treatment may be due to transcriptional activation or up-regulation of the TERT and/or TERC genes, as a result of DNA hypomethylation and/or histone modifications. Up-regulation of telomerase activity plateaus at a similar dose of $\mathrm{SAH}(0.5 \mathrm{mM})$ to that at which DNA demethylation levels off indicating some relationship between the amount of global DNA methylation and the telomerase activity levels. We suggest that SAH treatment induces high DNA hypomethylation and up-regulation of telomere activity without apparent arrest and apoptosis of the cell.

\section{Effect of SAH treatment on XCI}

The $\mathrm{XCl}$ status was assessed in the SAH-treated female fibroblast donor cells as a marker for associated epigenetic alterations induced by global DNA demethylation. $\mathrm{XCl}$ is a multistep epigenetically regulated process that begins soon after fertilization and is maintained in all female somatic cells throughout preand postnatal life (Heard 2004, Chang et al. 2006). Key to this gene silencing process is the establishment and maintenance of DNA and histone methylation, which alters the replication profile and transcriptional activity in the hypermethylated X-chromosome (Csankovszki 
et al. 2001). This process is initiated by the transcription of a non-coding sequence of RNA from the XIST (Xinactive-specific transcript) from the locus on the $\mathrm{X}$-chromosome to be inactivated. Subsequently, transcription of the majority of genes on that chromosome is reduced, histones $\mathrm{H} 3$ lysine 9 and lysine 27 become methylated, and the inactivated $\mathrm{X}$-chromosome becomes late replicating. Hypermethylation of CpGrich areas of the inactive $\mathrm{X}$-chromosome occurs as the last of the series of events in the inactivation process and is thought to play a role in the maintenance of the inactivation process rather than initiating it (reviewed by Chang et al. 2006). Examination of the X-chromosomes of cells treated with the demethylating agent 5-aza-dC has previously shown that the replication pattern is altered with a trend toward synchronous replication of the two X-chromosomes (Jablonka et al. 1987, Haaf et al. 1988) and an increase in the transcriptional activity of the X-linked gene, HPRT (Sasaki et al. 1992). The effect of SAH-induced demethylation in this context has not been previously reported. In the present study, SAH treatment of female fibroblasts induced the removal of histones $\mathrm{H} 3-3 \mathrm{mK} 9$ and $\mathrm{H} 3-3 \mathrm{mK} 27$ trimethylation on one of the $\mathrm{X}$-chromosomes, the presumptive $\mathrm{Xi}$, in over $40 \%$ and $82 \%$ of cells respectively. It has been demonstrated previously that DNA methylation is controlled by histone H3-K9 methylation (Tamaru \& Selker 2001, Lehnertz et al. 2003). Conversely, the distribution of $\mathrm{H} 3-3 \mathrm{mK} 27$ is directly influenced by DNA methylation, and the allocation of $\mathrm{H} 3-2 \mathrm{mK} 9, \mathrm{H} 3-$ $1 \mathrm{mK} 27$, and $\mathrm{H} 3-2 \mathrm{mK} 27$ histone modifications were not affected by changes in the methylation status of the DNA (Mathieu et al. 2005). Since methylation of histones $\mathrm{H} 3-3 \mathrm{mK} 9$ and $\mathrm{H} 3-3 \mathrm{mK} 27$ is achieved by histone methyltransferase as well (Peters et al. 2003, Plath et al. 2003), removal of $\mathrm{H} 3-3 \mathrm{mK} 9$ and $\mathrm{H} 3-3 \mathrm{mK} 27$ from the presumptive inactivated $\mathrm{X}$-chromosome may be also be due to the inhibition of histone methyltransferase, independent of the methylation status of the X-chromosome DNA. In earlier studies, the level of methylated $\mathrm{H} 3-\mathrm{K} 9$ histones was reduced in cells treated by increasing concentrations of $\mathrm{SAH}$ indicating that $\mathrm{SAH}$ or methyl donor deficiency inhibits $\mathrm{H} 3$ lysine 9 methylation activity (Kim et al. 2003). However, Fahrner et al. (2002) have suggested that methylation of $\mathrm{H} 3-\mathrm{K} 9$ is inhibited by 5 -aza-dC, which is a DNMT inhibitor, and not histone methyltransferase inhibitor. This implies that removal of both $\mathrm{H} 3-3 \mathrm{mK} 9$ and $\mathrm{H} 3-3 \mathrm{mK} 27$ methylation could also be related to $\mathrm{SAH}$-induced DNA hypomethylation. Interestingly, we have shown that the distribution pattern of these trimethylated histones, $\mathrm{H} 3-3 \mathrm{mK} 9$ and $\mathrm{H} 3-3 \mathrm{mK} 27$, on the presumptive $\mathrm{Xi}$ of SAH-treated cells is different (not entirely overlapping), suggesting that their establishment/maintenance may be modulated by other unknown factors.

In general, transcriptionally active euchromatin replicates during the first half of S-phase, whereas silent heterochromatin replicates during the second half. The mostly heterochromatic $\mathrm{Xi}$ is also characterized by late replication, compared with its activate homolog with early replication timing (Hansen et al. 1996, Mostoslavsky et al. 2001). The shift from synchronous replication to asynchronous (late) replication of the $\mathrm{X}$-chromosomes in female embryos of cattle and other species during development has been shown to occur after the initial expression of XIST (De La Fuente et al. 1999, Heard 2004) and associated with $\mathrm{H} 3$ trimethylation at lysine 9 (Chadwick \& Willard 2004) and 27 (Plath et al. 2003, Heard 2004) localized over the late replicating regions. Treatment of cells with SAH shifted the replication pattern of the presumptive $\mathrm{Xi}$ from late to intermediate or early replication in $63.9 \%$ of cells examined (vs $31.7 \%$ in untreated cells). However, it should be noted that determining the replication pattern of the X-chromosomes with BrdU is a sensitive method that requires a high degree of synchronization of the cells at the time of labeling (Di Berardino et al. 2002) and fixation such that even in untreated samples we detected asynchronous replication considered to result from the incomplete synchronization of the cell cultures at the time of BrdU administration (Ponce de Leon et al. 1992) in approximately one-third of the cells examined. Nonetheless, using this as a baseline value, SAH treatment clearly altered the X-chromosome replication pattern. Change in replication timing coincided with the immunochemical identification of changes in cytochemically detectable methylated domains of $\mathrm{H} 3-3 \mathrm{mK} 9$ and $\mathrm{H} 3-3 \mathrm{mK} 27$. Alteration of DNA methylation by 5 -aza-dC and histone methylation patterns with inhibitors of histone deacetylases have also been associated with alteration in replication timing of the late replicating X-chromosome (Bickmore \& Carothers 1995) suggesting that, as observed in the present study, disruption of both global DNA methylation and histones $\mathrm{H} 3$ lysine 9 and 27 methylation patterns is associated with heterochromatic DNA replication patterns. Although the methylation status of the inactivated X-chromosome was not specifically assessed in this study, the shift to early replication of the presumptive $\mathrm{Xi}$ in $\mathrm{SAH}$-treated cells corroborates the observed reduction in lysine trimethylation of $\mathrm{H} 3$ histones and predicts that the inactive $\mathrm{X}$-chromosome DNA was demethylated based on the known series of events for the inactivation process (Chang et al. 2006).

The main physiological outcome of $\mathrm{X}$-inactivation is the dosage compensation for $\mathrm{X}$-linked genes that manifests as transcriptional silencing of the majority of the loci on the $\mathrm{Xi}$ (Chang et al. 2006). Alteration in mechanisms that initiate or maintain the $X$-inactivation would be expected to alter the expression pattern of X-linked genes in female cells (Sasaki et al. 1992, Tinker \& Brown 1998). Generally, gene expression in demethylated cells has been shown to increase by the reactivation of silenced genes, as a result of CpG hypomethylation. DNA demethylation by SAH treatment showed up-regulation of genes related to cell 
growth/maintenance, metabolism and oxidoreductase activity induced in the SNU-16 gastric cancer cells (Lee et al. 2004), and gene expression has been also increased in human fibroblasts treated with 5-aza-dC (Liang et al. 2002). X-linked genes, such as G6PD, HPRT, PGK, and $T I M$, have been shown to be fully re-expressed on the $\mathrm{Xi}$ reactivated with synchronous replication timing by hybridization of chorionic villi cells from term placentas with mouse A9 cells (Luo et al. 1995) and HPRT mRNA has been highly increased on an inactive human $\mathrm{X}$-chromosome in a somatic cell hybrid with demethylation of the HPRT CpG promoter, following exposure to 5-aza-dC (Sasaki et al. 1992). The locus of the XIST gene is methylated in the active X-chromosome; however, after 5-aza-dC treatments, the XIST gene is expressed in the mouse/human somatic cell hybrid (Tinker \& Brown 1998). In the present study, only HPRT showed a significant increase in mRNA levels subsequent to SAH treatment. Interestingly, several of the genes, including XIST, showed a notable, albeit non-significant, increase in the level of expression in treated samples. HPRT is transcribed only from the active X-chromosome, but RPS4X and ZFX, both of which had expression levels that were unchanged by treatment, have functional Y-homologs, and are transcribed from both the active and inactive $X$-chromosome (Boggs \& Chinault 1994, Carrel etal. 1996, Brown \& Chow 2003). It is likely that gene loci escaping X-inactivation such as RPS4X and ZFX are not methylated on either of the $X$-chromosomes and hence were not affected by DNA demethylation with $\mathrm{SAH}$, whereas the transcript levels of other X-linked genes were slightly increased by SAH treatment. The non-significant elevation in the expression of $X$-linked genes might be a reflection of the heterogeneous population of cells in culture following treatment since only slightly more than half of the cells examined show alterations in replication timing and histone methylation patterns on the presumptive inactive X-chromosome. Moreover, since both of these events are downstream of transcriptional silencing, it is possible that $\mathrm{SAH}$ treatment, at the dose and times investigated here, was only able to partially reverse X-inactivation. This possibility was further supported by the fact that XIST expression, the initiating step in X-inactivation, was not reduced as might be expected if $X$-inactivation was fully reversed (Tinker \& Brown 1998).

\section{Effect of SAH treatment on SCNT embryo development}

Epigenetic reprogramming is a very important process in fertilization-derived and cloned embryo development (reviewed by Morgan et al. 2005). After fertilization, nuclear reprogramming, which erases some of the epigenetic modifications inherited from the gametes and establishes new zygotic patterns, is an essential process of normal embryogenesis and involves DNA demethylation and methylation events as well as other chromatin alterations (Morgan et al. 2005). In fertilization-derived bovine embryos, the paternal genome is actively demethylated at the zygote stage while methylation of the maternal genome is reduced passively upon cleavage up to the eight-cell stage, followed by a de novo methylation event at the 16-cell stage (Dean et al. 2001, Reik et al. 2001). However, in the SCNT bovine embryos, active demethylation occurs at the onecell stage with no further demethylation occurring subsequently (Bourc'his et al. 2001, Kang et al. 2001). At the morula stage, all nuclei of blastomeres appeared highly methylated, resembling those of the differentiated somatic donor cells. It has been suggested that epigenetic reprogramming occurs aberrantly and incompletely in a significant portion of cloned embryos (Dean et al. 2001) resulting in aberrant gene expression and abnormal development (Morgan et al. 2005). Moreover, it has been shown that H3-K9 methylation is reprogrammed in parallel with DNA methylation and reveals an association between epigenetic marks and developmental potential (Santos et al. 2003). The majority of cloned embryos in that study exhibited H3-K9 hypermethylation associated with DNA hypermethylation suggesting genome-wide failure in reprogramming dependent on the donor cell type (Santos et al. 2003).

Donor cell treatment with DNMT inhibitor, 5-aza-dC and/or the histone deacetylase inhibitor, Trichostatin A have been used to induce widespread reductions in DNA methylation and increase in histone acetylation levels respectively in donor cells before nuclear transfer (Enright et al. 2003, 2005, Shi et al. 2003). Although 5-aza-dC-treated cells reduced DNA methylation levels, the donor cells are induced to undergo senescence by the deleterious side effects of 5-aza-dC treatment and subsequent in vitro development does not improve for the SCNT embryos derived from them (Enright et al. 2003, Shi et al. 2003). 5-Aza-dC treatment at much lower concentrations $(0.01 \mu \mathrm{M})$ did not impose deleterious effects on the development of embryos cloned from treated cells, although these embryos were not evaluated for pregnancy outcomes (Enright et al. 2005). Although embryo transfers and pregnancy monitoring still have to be carried out, we have demonstrated a significant improvement in the frequency of blastocyst development for embryos cloned with SAH-treated donor cells compared with non-treated controls.

To support the supposition that nuclear reprogramming was improved in embryos cloned from SAH-treated donor cells, we measured telomerase activity in the resultant blastocysts. Generally, the presence of telomerase activity is associated with the undifferentiated state and cellular immortality, while cellular aging and senescence result in cells that lack telomerase (reviewed by Greider 1998). Telomerase levels are quite high in mammalian embryos (Betts \& King 1999) but diminish during cellular differentiation (Yamada et al. 1998), thus making it a good marker for assessing nuclear reprogramming efficiency during cloned embryo development 
(Betts et al. 2001). We have demonstrated that using hypomethylated donor somatic cells increases the developmental potential of the resultant SCNT embryos possibly by enhancing the nuclear reprogramming efficiency as evident by increased telomerase activity levels. Changes to the DNA methylation and histone methylation status of donor somatic cells by $\mathrm{SAH}$ treatment may contribute to enhanced nuclear reprogramming efficiency of the SCNT embryos by producing epigenetic characteristics more like those of normal fertilized embryos. Alternatively, the observed improvement in development for embryos cloned from the SAH-treated donor cells may be due solely by the up-regulation of telomerase itself. Telomerase provides chromosomal/genomic stability and increased levels during early development may provide the SCNT embryos some protection against apoptosis or to better enable DNA repair mechanisms aiding development in suboptimal culture environments (Izbicka et al. 1999). In addition, up-regulation of telomerase has been shown to increase proliferation, cell survival, and possibly alter cell state to a more undifferentiated, progenitor-like condition (Perrault et al. 2005).

Even though the use of hypomethylated donor cells increases the developmental potential of SCNT embryos during pre-implantation development and holds promise for the improvement of SCNT embryo developmental potential, the possibility for developmental abnormalities related to aberrant expression of $X$-linked and imprinted genes exists. Further exploration of development beyond the blastocyst stage in terms of gene expression in addition to fetal anatomy and physiology is required.

\section{Materials and Methods}

All chemicals and reagents used in this study were purchased from the Sigma Chemical Company and Gibco BRL, unless otherwise stated.

\section{Preparation and demethylation treatment of cells}

Primary cultures of bovine female adult crossbred beef ear skin fibroblasts ( $\sim 4$ years old) were established from a piece of ear tissue and stored in $\mathrm{LN}_{2}$ until required. For each experiment, frozen cells were thawed and cultured in Dulbecco's Modified Eagle's Medium (DMEM) supplemented with 10\% (v/v) fetal bovine serum (FBS) and $1 \%(\mathrm{v} / \mathrm{v})$ penicillin-streptomycin (10 $000 \mathrm{IU}$ and $10000 \mu \mathrm{g} / \mathrm{ml}$ respectively; Invitrogen). The cells at the third passage were cultured in DMEM plus 10\% FBS and $1 \%$ Pen-Strep containing 0 (control), 0.1, 0.25, 0.5, 1.0, and $2.0 \mathrm{mM}$ SAH in 4-well dishes (Nunc, Roskild, Denmark) for an additional two passages until confluence (5 days) with the culture media being changed daily with fresh DMEM containing respective concentrations of SAH. The cells were then dissociated in $0.25 \%$ trypsin with $0.04 \%$ EDTA and immediately analyzed for global demethylation or frozen at $-80^{\circ} \mathrm{C}$ for future analysis of RTA.

\section{Quantification of global DNA methylation}

The immunostaining method for the detection of 5-methylcytosine was used as described previously by Castilho et al. (1999). Briefly, fully confluent SAH-treated cells at various concentrations were exposed to warm $0.075 \mathrm{M} \mathrm{KCl}$ for $20 \mathrm{~min}$, followed by fixation in methanol and acetic acid $(3: 1)$ overnight at $4{ }^{\circ} \mathrm{C}$. The fixed cells were spread onto pre-cleaned wet slides and air-dried. The slides were treated with RNase $(10 \mu \mathrm{g} / \mathrm{ml})$ and pepsin $(0.1 \mathrm{mg} / \mathrm{ml})$ for $1 \mathrm{~h}$ at $37^{\circ} \mathrm{C}$, dehydrated in $70 \%$ and $100 \%$ ethanol and air-dried. The slides were treated with $4 \mathrm{M} \mathrm{HCl}$ for $15 \mathrm{~min}$ at room temperature (RT), washed with PBS, and blocked for $30 \mathrm{~min}$ at RT in PBST (PBS containing $0.05 \%(\mathrm{v} / \mathrm{v})$ Tween 20$)$ supplemented with $1 \%(\mathrm{v} / \mathrm{v})$ BSA (essentially fatty acid free). The slides were incubated with mouse MAB against 5-methylcytosine (1:200 dilution; VWR Laboratories, Mississauga, ON, Canada) in PBS at $37^{\circ} \mathrm{C}$ for $1 \mathrm{~h}$, followed by three washes with PBST and incubation in PBS containing an FITC-conjugated anti-mouse secondary antibody (1:200 dilution; Abcam, Cambridge, MA, USA) at $37{ }^{\circ} \mathrm{C}$ for $1 \mathrm{~h}$. Finally, the slides were washed with PBST and mounted with Vectashield mounting medium (Vector Laboratory Canada Inc., Burlington, USA) containing $1 \mu \mathrm{g} / \mathrm{ml} \mathrm{4}{ }^{\prime}, 6^{\prime}$-diamidino-2-phenylindole (DAPI) for staining DNA. The slides were observed under a Leitz fluorescence microscope (Leica, Wetzlar, Germany). Openlab Leica image processing software (Improvision, Lexington, MA, USA) equipped with the microscope was used for image acquisition and quantitative measurements of the RFI emitted by each individual nucleus. Every slide was analyzed using the same optical conditions. At least 100 nuclei were analyzed for each SAH treatment.

\section{Relative-quantitative telomerase repeat amplification protocol (RQ-TRAP)}

The RQ-TRAPassay was modified from a conventional TRAPassay for use on the LightCycler 3.0 (Roche) as described previously by Betts et al. (2006). Briefly, after harvesting $1 \times 10^{5}$ cells treated with various SAH concentrations and SCNT embryos developed to blastocyst on day 9 , samples were either immediately frozen at $-80{ }^{\circ} \mathrm{C}$ for future analysis or lysed. The samples were lysed in $0.5 \%$ (v/v) 3-[(3-cholamidopropyl) dimethylammonio] propanesulfonic acid lysate buffer ( $\mathrm{pH}$ 7.5) supplemented with $10 \mathrm{mM}$ Tris- $\mathrm{HCl}, 1 \mathrm{mM} \mathrm{MgCl}$, $1 \mathrm{mM}$ EGTA, $0.1 \mathrm{mM}$ benzamidine, $5 \mathrm{mM}$ of 2-mercaptoethanol, and $10 \%$ glycerol at a concentration of $250 \mathrm{cells} / \mu \mathrm{l}$ for $30 \mathrm{~min}$ on ice. Following lysis, the samples were centrifuged for $20 \mathrm{~min}$ at $12000 \mathrm{~g}$ at $4{ }^{\circ} \mathrm{C}$ to remove cell debris. Eighty percent (by volume) of the lysis was then transferred to a fresh microcentrifuge tube and analyzed using RQ-TRAP. Each run included measurements of 1000,100, 10, and 1293 T (Chemicon/ Millipore, Lake Placid, NY, USA) telomerase-positive control cell(s) for the generation of a standard curve. As a negative control, a portion of the 293T sample was heat inactivated by incubation for $10 \mathrm{~min}$ at $85^{\circ} \mathrm{C}$. The RQ-TRAP was optimized using the PCR reagent LightCycler FastStart DNA Master SYBR Green I (Roche), according to the manufacturer's protocol, containing $2.5 \mathrm{mM}$ $\mathrm{MgCl}_{2}, 0.02 \mu \mathrm{g}$ primer TS (5'-AAT CCG TCG GAG CAG AGT T-3'), $0.04 \mu \mathrm{g}$ primer ACX (5'-GCG CGG CTT ACC CTT ACC CTT ACC (TA ACC- $\left.3^{\prime}\right)$, and $2 \mu$ of each 250 cells/ $\mu$ l sample to be analyzed. 
The assay run included $20-\mathrm{min}$ incubation at $25^{\circ} \mathrm{C}$, followed by 10-min incubation at $94{ }^{\circ} \mathrm{C}$, and 40 cycles of PCR at $94{ }^{\circ} \mathrm{C}$ for $30 \mathrm{~s}$ and $60{ }^{\circ} \mathrm{C}$ for $90 \mathrm{~s}$. All the samples were quantified using the LightCycler Quantification Software's (Roche) second derivative method of crossing point (Cp) determination, which was then compared with the 293T cell standard curve generated, and activity expressed as RTA to 293T cells on a per cell basis.

\section{Distribution analysis of H3-3mK9 and H3-3mK27}

Metaphase chromosomes and immunostaining of $\mathrm{H} 3-3 \mathrm{mK} 9$ and $\mathrm{H} 3-3 \mathrm{mK} 27$ were prepared as described previously with minor modifications by Belyaev et al. (1996). Briefly, the cells at the third passage were treated with 0 (control) and $1.0 \mathrm{mM}$ $\mathrm{SAH}$ during the two passages until confluence. After reseeding, the growing cells treated with 0 (control) and $1.0 \mathrm{mM} \mathrm{SAH}$ were arrested at M-phase with $0.05 \mu \mathrm{g} / \mathrm{ml}$ demecolcine (colcemid) treatment for $2 \mathrm{~h}$. Mitotic cells were collected by vigorously shaking the flasks and treated with warm $\mathrm{KCl}$ $(0.075 \mathrm{~mol} / \mathrm{l})$ for $10 \mathrm{~min}$, and then spread onto the slides using a Shandon Cytospin Centrifuge (Thermo-Fisher, Whitby, ON, Canada) at $500 \mathrm{~g}$ at $10 \mathrm{~min}$. The slides were immersed in $\mathrm{KCM}$ buffer $(120 \mathrm{mM} \mathrm{KCl}, 20 \mathrm{mM} \mathrm{NaCl}, 10 \mathrm{mM}$ Tris- $\mathrm{HCl}(\mathrm{pH}$ 8), $0.5 \mathrm{mM}$ EDTA, and $0.1 \%$ Triton X-100) for $10 \mathrm{~min}$, followed by fixation in $4 \%$ formaldehyde (in PBS) for 5 min, washed with $0.04 \%$ Photoflo (in $\mathrm{H}_{2} \mathrm{O}$; Kodak) for $5 \mathrm{~min}$, and air-dried. The slides were blocked for $30 \mathrm{~min}$ at RT in PBST supplemented with $1 \%$ BSA and incubated in PBST containing mouse rabbit anti-H3-3mK9 (1:100 dilution; Abcam) and mouse anti-H33 mK27 (dilution 1:100; Abcam) overnight at $4{ }^{\circ} \mathrm{C}$ and incubated in PBS containing a anti-rabbit Alexa 594-coupled antibody (1:100 dilution; Abcam) for the detection of H3-3mK9 and FITC-conjugated anti-mouse secondary antibody (1:100 dilution, Abcam) for the detection of $\mathrm{H} 3-3 \mathrm{mK} 27$ at $37^{\circ} \mathrm{C}$ for $1 \mathrm{~h}$. Finally, the slides were washed with PBST and mounted with Vectashield mounting medium containing $1 \mu \mathrm{g} / \mathrm{ml}$ DAPI for staining DNA. Image acquisition and analysis were carried out as described above.

\section{Replication timing assay}

The replication timing of the $\mathrm{X}$-chromosomes was analyzed using RBA orange of metaphase spreads as described previously by Di Berardino et al. (2002). Briefly, after trypsinization of the cells previously treated with 0 (control) and $1.0 \mathrm{mM} \mathrm{SAH}$ for the two passages until confluence, the cells were cultured for $3 \mathrm{~h}$ and then synchronized at the middle of S-phase with $300 \mu \mathrm{g} / \mathrm{ml}$ thymidine for $16 \mathrm{~h}$. This cell cycle block was released with two washes with fresh DMEM, and then the cells were allowed to resume their cell cycle in DMEM, supplemented with $20 \mu \mathrm{g} / \mathrm{ml}$ BrdU, a thymidine analog. After $7 \mathrm{~h}$ of culture, cells at metaphase were harvested and treated with warm $0.075 \mathrm{M}$ $\mathrm{KCl}$ for $20 \mathrm{~min}$, followed by fixation in cold methanol:acetic acid $(3: 1, v / v)$ overnight at $4{ }^{\circ} \mathrm{C}$. The fixed cells were spread onto pre-cleaned wet slides, air-dried, and stained with $0.1 \%$ acridine orange solution in PBS ( $\mathrm{pH} 7.0)$ for 10 min, washed thoroughly in tap water, mounted in phosphate buffer, and sealed with nail cement. Image acquisition and analysis were carried out as described earlier.

\section{Quantitative analysis of transcripts by real time RT-PCR}

Total RNA of the fully confluent control and the SAH-treated cells was extracted using the QIA shredder column and Qiagen RNeasy Micro Kit (Qiagen). Homogenization, isolation, precipitation, and purification of RNA were performed, according to the manufacturer's procedure with an extra step of DNase I treatment for the removal of DNA contamination. The concentration of extracted total RNA was determined by measuring the absorbance at $260 \mathrm{~nm}$ in a spectrophotometer. Two micrograms of total RNA was synthesized for the firststrand cDNA with Omniscript RT Kit (Qiagen). Each of the cDNA samples contained $2 \mu$ of $10 \mu \mathrm{M}$ oligo(dT) 12-18 $_{18}$ primer (Invitrogen), $1 \mu \mathrm{l}$ of $10 \mathrm{U} / \mu \mathrm{l}$ RNase inhibitor (Fisher Scientific, Whitby, ON, Canada), $2 \mu \mathrm{l}$ RT buffer, $2 \mu \mathrm{l} \mathrm{dNTP}$, and $1 \mu \mathrm{l}$ Omniscript (Qiagen), adjusted to a total volume of $20 \mu \mathrm{l}$ using $\mathrm{H}_{2} \mathrm{O}$. The cDNA samples were then incubated in a PTC-200 Peltier Thermal Cycler (MJ Research, Waltham, MA, USA) at $42{ }^{\circ} \mathrm{C}$ for $1 \mathrm{~h}$, followed by $5 \mathrm{~min}$ at $95^{\circ} \mathrm{C}$ to inactivate the enzyme. A total of three RT reactions were used for each RNA sample. The real-time RT-PCR was carried out using the LightCycler 3.0 and the LightCycler FastStart DNA Master SYBR Green I (Roche), according to the manufacturer's protocols. Each reaction mix contained $2 \mu \mathrm{l}$ of the cDNA reaction, $2 \mu \mathrm{l}$ of the FastStart DNA Master SYBR Green I reaction mix, $3 \mathrm{mM} \mathrm{MgCl}$, and $2 \mu$ of each the forward and reverse primers $(0.1 \mu \mathrm{g} / \mu \mathrm{l})$, adjusted to a total volume of $20 \mu \mathrm{l}$ using $\mathrm{H}_{2} \mathrm{O}$. X-linked genes (ANT3, HPRT, MECP2, RPS4X, $X I A P, X I S T, Z F X)$ and autosomal genes $(A C T B, H 2 A)$ were analyzed for the pattern of the transcripts by quantitative realtime RT-PCR. Primer sequences, the size of amplified products, and the GenBank accession numbers are shown in Table 4. The annealing and acquisition temperatures of primer were used as described previously by Nino-Soto et al. (2005). In each of the cDNA samples, at least five replicates of PCRs were carried out.

\section{SCNT and embryo culture}

Cells at the third passage were treated with control and $1.0 \mathrm{mM}$ $\mathrm{SAH}$ for an additional two passages until confluence and dissociated in $0.25 \%$ trypsin in EDTA immediately before nuclear transfer. Immature bovine oocytes obtained from slaughterhouse ovaries were in vitro matured in TCM-199 containing $2.5 \mathrm{mM}$ Na pyruvate, $1 \mathrm{mM}$ L-glutamine, $1 \%(\mathrm{v} / \mathrm{v})$ Pen-Strep, $2 \%$ steer serum (PAA Laboratories, Etobicoke, ON, Canada), $1 \mu \mathrm{g} / \mathrm{ml}$ estradiol- $17 \beta, 0.5 \mu \mathrm{g} / \mathrm{ml}$ follicle-stimulating hormone, and $1 \mu \mathrm{g} / \mathrm{ml}$ luteinizing hormone (USDA National Hormone and Peptide Program, UCLA Medical Center, Torrance, CA, USA) at $38.5^{\circ} \mathrm{C}$ in a humidified atmosphere of $5 \% \mathrm{CO}_{2}$ in air. After $18 \mathrm{~h}$ of culture, the oocytes denuded by vortexing for $2 \mathrm{~min}$ in $3 \%(\mathrm{v} / \mathrm{v})$ sodium citrate solution were enucleated in HEPES-buffered Tyrode's salt solution with albumin, lactate, and pyruvate (HEPES-TALP), and successfully enucleated oocytes were selected by a short 1-2 s exposure of the pipette containing aspirated cytoplasm stained with $5 \mu \mathrm{g} / \mathrm{ml}$ bisbenzimide (Hoechst 33342) to u.v. light. Donor cells with intact membranes were selected and transferred to the perivitelline space of each enucleated oocyte. Oocyte-donor cell complexes were fused with two electric pulses at 
Table 4 Sequence-specific primers used for RT-PCR.

\begin{tabular}{|c|c|c|c|c|c|}
\hline Gene & Primer sequences $\left(5^{\prime}-3^{\prime}\right)$ & $\begin{array}{l}\text { PCR product } \\
\text { band size }(b p)\end{array}$ & $\begin{array}{c}\text { Annealing } \\
\text { temperature }\left({ }^{\circ} \mathrm{C}\right)\end{array}$ & $\begin{array}{c}\text { Acquisition } \\
\text { temperature }\left({ }^{\circ} \mathrm{C}\right)\end{array}$ & $\begin{array}{c}\text { GenBank accession } \\
\text { number }\end{array}$ \\
\hline$A C T-B$ & $\begin{array}{l}\text { F-CGTGACATTAAGGAGAAGCTGTGC } \\
\text { R-CTCAGGAGGAGCAATGATCTTGAT }\end{array}$ & 374 & 63 & 86 & ВС008633 \\
\hline $\mathrm{H} 2 \mathrm{~A}$ & $\begin{array}{l}\text { F-GTCGTGGCAAGCAAGGAG } \\
\text { R-GATCTCGGCCGTTAGGTACTC }\end{array}$ & 182 & 59 & 87 & U62674 \\
\hline ANT3 & $\begin{array}{l}\text { F-TTCCCTGTGCTTCGTCTACC } \\
\text { R-TGCCCTTGTACATGATGTCG }\end{array}$ & 383 & 60 & 89 & NM_001636 \\
\hline HPRT & $\begin{array}{l}\text { F-CGAGATGTGATGAAGGAGATGG } \\
\text { R-TTTCAAATCCAACAAAGTCTGG }\end{array}$ & 397 & 61 & 81 & NM_001034035 \\
\hline MECP & $\begin{array}{l}\text { F-GGGACCCATGTATGATGACC } \\
\text { R-ATGTGTCGCCTACCTTTTCG }\end{array}$ & 173 & 60 & 81 & NM_004992 \\
\hline RPS4X & $\begin{array}{l}\text { F-ATTAAGATCGATGGCAAAGTCC } \\
\text { R-AAAAGAACCTGGATGTCTCTCC }\end{array}$ & 408 & 59 & 80 & XM_591678 \\
\hline$X I A P$ & $\begin{array}{l}\text { F-GGCGACACTTTCCTAATTGC } \\
\text { R-AAGCATAAAATCCAGCTCTTGC }\end{array}$ & 213 & 58 & 78 & NM_001167 \\
\hline$X I S T$ & $\begin{array}{l}\text { F-CCTTGTCATGTGGATATCATGG } \\
\text { R-AATGTCCTTGGAAAGACTTTGG }\end{array}$ & 224 & 59 & 84 & NR_001464 \\
\hline$Z F X$ & $\begin{array}{l}\text { F-TCTATCCTTGCATGATTTGTGG } \\
\text { R-AGAGTCTGCGGACCTATATTCG }\end{array}$ & 494 & 57 & 83 & NM_003410 \\
\hline
\end{tabular}

$1.0 \mathrm{kV} / \mathrm{cm}$ for $15 \mu \mathrm{s}$ in $0.26 \mathrm{M}$ mannitol solution supplemented with $50 \mu \mathrm{M} \mathrm{MgCl}_{2}$ using an ECM 2001 BTX cell manipulator (VWR Laboratories) equipped with electrode needles. After $1 \mathrm{~h}$, the eggs were assessed for successful fusion. Fused oocytes were subsequently activated with $5 \mu \mathrm{M}$ ionomycin in HEPESTALP for $5 \mathrm{~min}$, followed by exposure to in vitro culture (IVC) medium containing $10 \mu \mathrm{g} / \mathrm{ml}$ cycloheximide (CHX). After incubation with $\mathrm{CHX}$ for $5 \mathrm{~h}$ at $38.5^{\circ} \mathrm{C}$, reconstructed embryos were transferred to the IVC medium, which was modified synthetic oviduct fluid (mSOF) supplemented with $2.9 \mu \mathrm{g} / \mathrm{ml}$ EDTA and $8 \mathrm{mg} / \mathrm{ml} \mathrm{BSA}$ up to day 3 . On day 3 of the culture, the embryos were transferred to mSOF supplemented with $8 \mathrm{mg} / \mathrm{ml} \mathrm{BSA}$ and MEM amino acids until day 9 (Mastromonaco et al. 2004). All IVC culture was at $38.5^{\circ} \mathrm{C}$ in a humidified atmosphere of $5 \% \mathrm{CO}_{2}, 5 \% \mathrm{O}_{2}$, and $90 \% \mathrm{~N}_{2}$. Cleavage and blastocyst frequencies were recorded on days 2 and 9 respectively. Total and inner cell mass cell numbers and RTA levels of the SCNT embryos developed to hatched blastocyst on day 9 were determined by the differential staining method (Thouas et al. 2001) and RQ-TRAP assay described earlier.

\section{Statistical analysis}

Differences among treatments were analyzed using one-way ANOVA, those in the RFI, RTA, and transcript level of $\mathrm{X}$-chromosome genes using Student's $t$-test, and those in the incorporation of $\mathrm{H} 3-3 \mathrm{mK} 27$ and $\mathrm{H} 3-3 \mathrm{mK} 9$, late replication, and development in vitro into blastocyst stage using $\chi^{2}$ test. $P<0.05$ was used as the level of significance.

\section{Acknowledgements}

We would like to thank Liz St John and Ed R Reyes for technical assistance, and this work was funded by CIHR, NSERC, and CRC. B-G J was the recipient of an OECD CRP fellowship. The authors declare that there is no conflict of interest that would prejudice the impartiality of this scientific work.

\section{References}

Avner P \& Heard E 2001 X-chromosome inactivation: counting, choice and initiation. Nature Reviews. Genetics 2 59-67.

Bechter OE, Eisterer W, Dlaska M, Kuhr T \& Thaler J 2002 CpG island methylation of the hTERT promoter is associated with lower telomerase activity in B-cell lymphocytic leukemia. Experimental Hematology $\mathbf{3 0}$ 26-33.

Belyaev N, Keohane AM \& Turner BM 1996 Differential underacetylation of histones $\mathrm{H} 2 \mathrm{~A}, \mathrm{H} 3$ and $\mathrm{H} 4$ on the inactive $\mathrm{X}$ chromosome in human female cells. Human Genetics 97 573-578.

Di Berardino D, Coppola G, Verdoliva C, Coppola GF, Ramunno L, Enne G, Di Meo GP \& Iannuzzi L 2002 Onset and sequence of RBA-band replication on the inactive X-chromosomes of cattle (Bos taurus L.), river buffalo (Bubalus bubalis L.) and goat (Capra hircus L). Chromosome Research 10 637-643.

Betts DH \& King WA 1999 Telomerase activity and telomere detection during early bovine development. Developmental Genetics 25 397-403.

Betts D, Bordignon V, Hill J, Winger Q, Westhusin M, Smith L \& King W 2001 Reprogramming of telomerase activity and rebuilding of telomere length in cloned cattle. PNAS 98 1077-1082.

Betts DH, Perrault S, Harrington L \& King WA 2006 Quantitative analysis of telomerase activity and telomere length in domestic animal clones. Methods in Molecular Biology 325 149-180.

Bickmore WA \& Carothers AD 1995 Factors affecting the timing and imprinting of replication on a mammalian chromosome. Journal of Cell Science 108 2801-2809.

Bird A 2002 DNA methylation patterns and epigenetic memory. Genes and Development 16 6-21.

Blasco MA 2003 Mammalian telomeres and telomerase: why they matter for cancer and aging. European Journal of Cell Biology 82 441-446.

Boggs BA \& Chinault AC 1994 Analysis of replication timing properties of human X-chromosomal loci by fluorescence in situ hybridization. PNAS 91 6083-6087.

Bourc'his D, Le Bourhis D, Patin D, Niveleau A, Comizzoli P, Renard JP \& Viegas-Pequignot E 2001 Delayed and incomplete reprogramming of chromosome methylation patterns in bovine cloned embryos. Current Biology 11 1542-1546.

Brockdorff N 2002 X-chromosome inactivation: closing in on proteins that bind Xist RNA. Trends in Genetics 18 352-358.

Brown CJ \& Chow JC 2003 Beyond sense: the role of antisense RNA in controlling Xist expression. Seminars in Cell and Developmental Biology 14 341-347.

De Cabo SF, Hazen MJ, Molero ML \& Fernandez-Piqueras J 1994 Sadenosyl-L-homocysteine: a non-cytotoxic hypomethylating agent. Experientia 50 658-659. 
Carrel L, Hunt PA \& Willard HF 1996 Tissue and lineage-specific variation in inactive $\mathrm{X}$ chromosome expression of the murine Smcx gene. Human Molecular Genetics 5 1361-1366.

Castilho A, Neves N, Rufini-Castiglione M, Viegas W \& Heslop-Harrison JS 1999 5-Methylcytosine distribution and genome organization in triticale before and after treatment with 5-azacytidine. Journal of Cell Science 112 4397-4404.

Castro R, Rivera I, Martins C, Struys EA, Jansen EE, Clode N, Graca LM, Blom HJ, Jakobs C \& de Almeida IT 2005 Intracellular $S$-adenosylhomocysteine increased levels are associated with DNA hypomethylation in HUVEC. Journal of Molecular Medicine 83 831-836.

Caudill MA, Wang JC, Melnyk S, Pogribny IP, Jernigan S, Collins MD, Santos-Guzman J, Swendseid ME, Cogger EA \& James SJ 2001 Intracellular $S$-adenosylhomocysteine concentrations predict global DNA hypomethylation in tissues of methyl-deficient cystathionine beta-synthase heterozygous mice. Journal of Nutrition 131 2811-2818.

Chadwick BP \& Willard HF 2004 Multiple spatially distinct types of facultative heterochromatin on the human inactive $\mathrm{X}$ chromosome. PNAS 101 17450-17455.

Chang SC, Tucker T, Thorogood NP \& Brown CJ 2006 Mechanisms of $\mathrm{X}$-chromosome inactivation. Frontiers in Bioscience 11 852-866.

Christman JK 2002 5-Azacytidine and 5-aza-2'-deoxycytidine as inhibitors of DNA methylation: mechanistic studies and their implications for cancer therapy. Oncogene 21 5483-5495.

Cong YS, Wen J \& Bacchetti S 1999 The human telomerase catalytic subunit hTERT: organization of the gene and characterization of the promoter. Human Molecular Genetics 8 137-142.

Csankovszki G, Nagy A \& Jaenisch R 2001 Synergism of Xist RNA, DNA methylation, and histone hypoacetylation in maintaining $X$ chromosome inactivation. Journal of Cell Biology 153 773-784.

Dean W, Santos F, Stojkovic M, Zakhartchenko V, Walter J, Wolf E \& Reik W 2001 Conservation of methylation reprogramming in mammalian development: aberrant reprogramming in cloned embryos. PNAS 98 13734-13738.

De La Fuente R, Hahnel A, Basrur PK \& King WA 1999 X inactive-specific transcript (Xist) expression and $\mathrm{X}$ chromosome inactivation in the preattachment bovine embryo. Biology of Reproduction 60 769-775.

Dessain SK, Yu H, Reddel RR, Beijersbergen RL \& Weinberg RA 2000 Methylation of the human telomerase gene CpG island. Cancer Research 60 537-541.

Enright BP, Kubota C, Yang X \& Tian XC 2003 Epigenetic characteristics and development of embryos cloned from donor cells treated by trichostatin A or 5-aza-2'-deoxycytidine. Biology of Reproduction 69 896-901.

Enright BP, Sung LY, Chang CC, Yang X \& Tian XC 2005 Methylation and acetylation characteristics of cloned bovine embryos from donor cells treated with 5-aza-2'-deoxycytidine. Biology of Reproduction $\mathbf{7 2}$ 944-948.

Fahrner JA, Eguchi S, Herman JG \& Baylin SB 2002 Dependence of histone modifications and gene expression on DNA hypermethylation in cancer. Cancer Research 62 7213-7218.

Garcia-Cao M, O'Sullivan R, Peters AH, Jenuwein T \& Blasco MA 2004 Epigenetic regulation of telomere length in mammalian cells by the SUV39H1 and SUV39H2 histone methyltransferases. Nature Genetics 36 94-99.

Gonzalo S, Jaco I, Fraga MF, Chen T, Li E, Esteller M \& Blasco MA 2006 DNA methyltransferases control telomere length and telomere recombination in mammalian cells. Nature Cell Biology 8 416-424.

Greider CW 1998 Telomerase activity, cell proliferation and cancer. PNAS 95 90-92.

Guilleret I \& Benhattar J 2003 Demethylation of the human telomerase catalytic subunit (hTERT) gene promoter reduced hTERT expression and telomerase activity and shortened telomeres. Experimental Cell Research 289 326-334.

Haaf T, Ott G \& Schmid M 1988 Inhibition of condensation in the latereplicating $\mathrm{X}$ chromosome induced by 5 -azadeoxycytidine in human lymphocyte cultures. Human Genetics 79 18-23.

Han YM, Kang YK, Koo DB \& Lee KK 2003 Nuclear reprogramming of cloned embryos produced in vitro. Theriogenology 59 33-44.

Hansen RS, Canfield TK, Fjeld AD \& Gartler SM 1996 Role of late replication timing in the silencing silencing of X-linked genes. Human Molecular Genetics 5 1345-1353.
Heard E 2004 Recent advances in X-chromosome inactivation. Current Opinion in Cell Biology 16 247-255.

Herath CB, Ishiwata $H$, Shiojima S, Kadowaki T, Katsuma S, Ushizawa K, Imai K, Takahashi T, Hirasawa A, Takahashi S et al. 2006 Developmental aberrations of liver gene expression in bovine fetuses derived from somatic cell nuclear transplantation. Cloning and Stem Cells 8 79-95.

Hermes M, Osswald H, Mattar J \& Kloor D 2004 Influence of an altered methylation potential on mRNA methylation and gene expression in HepG2 cells. Experimental Cell Research 294 325-334.

Izbicka E, Nishioka D, Marcell V, Raymond E, Davidson KK, Lawrence RA, Wheelhouse RT, Hurley LH, Wu RS \& Von Hoff DD 1999 Telomereinteractive agents affect proliferation rates and induce chromosomal destabilization in sea urchin embryos. Anti-Cancer Drug Design 14 355-365.

Jablonka E, Goitein R, Sperling K, Cedar H \& Marcus M 1987 5-aza-Cinduced changes in the time of replication of the $X$ chromosomes of Microtus agrestis are followed by non-random reversion to a late pattern of replication. Chromosoma 95 81-88.

Kang YK, Koo DB, Park JS, Choi YH, Chung AS, Lee KK \& Han YM 2001 Aberrant methylation of donor genome in cloned bovine embryos. Nature Genetics 28 173-177.

Keohane AM, Barlow AL, Waters J, Bourn D \& Turner BM 1999 H4 acetylation, XIST RNA and replication timing are coincident and define $\mathrm{x}$; autosome boundaries in two abnormal $\mathrm{X}$ chromosomes. Human Molecular Genetics 8 377-383.

Kim KC, Geng L \& Huang S 2003 Inactivation of a histone methyltransferase by mutations in human cancers. Cancer Research 63 7619-7623.

Lanza RP, Cibelli JB, Blackwell C, Cristofalo VJ, Francis MK, Baerlocher GM, Mak J, Schertzer M, Chavez EA, Sawyer N, Lansdorop PM \& West MD 2000 Extension of cell life-span and telomere length in animals cloned from senescent somatic cells. Science 288 665-669.

Lee HS, Park MH, Yang SJ, Jung HY, Byun SS, Lee DS, Yoo HS, Yeom YI \& Seo SB 2004 Gene expression analysis in human gastric cancer cell line treated with trichostatin A and S-adenosyl-L-homocysteine using CDNA microarray. Biological \& Pharmaceutical Bulletin 27 1497-1503.

Lehnertz B, Ueda Y, Derijck AA, Braunschweig U, Perez-Burgos L, Kubicek S, Chen T, Li E, Jenuwein T \& Peters AH 2003 Sur39h-mediated histone H3 lysine 9 methylation directs DNA methylation to major satellite repeats at pericentric heterochromatin. Current Biology 13 1192-1200.

Li X, Amarnath D, Kato Y \& Tsunoda Y 2006 Analysis of developmentrelated gene expression in cloned bovine blastocysts with different developmental potential. Cloning and Stem Cells 8 41-50.

Liang G, Gonzales FA, Jones PA, Orntoft TF \& Thykjaer T 2002 Analysis of gene induction in human fibroblasts and bladder cancer cells exposed to the methylation inhibitor 5-aza-2-deoxycytidine. Cancer Research 62 961-966.

Luo S, Torchia BS \& Migeon BR 1995 XIST expression is re-pressed when X inactivation is reversed in human placental cells: a model for study of XIST regulation. Somatic Cell and Molecular Genetics 21 51-60.

Mastromonaco GF, Semple E, Robert C, Rho GJ, Betts DH \& King WA 2004 Different culture media requirements of IVF and nuclear transfer bovine embryos. Reproduction in Domestic Animals 39 462-467.

Masutomi K, Yu EY, Khurts S, Ben-Porath I, Currier JL, Metz GB, Brooks MW, Kaneko S, Murakami S, DeCaprio JA et al. 2003 Telomerase maintains telomere structure in normal human cells. Cell 114 241-253.

Mathieu O, Probst AV \& Paszkowski J 2005 Distinct regulation of histone $\mathrm{H} 3$ methylation at lysines 27 and 9 by $\mathrm{CpG}$ methylation in Arabidopsis. EMBO Journal 24 2783-2791.

Mohana Kumar B, Jin HF, Kim JG, Song HJ, Hong Y, Balasubramanian S, Choe SY \& Rho GJ 2006 DNA methylation levels in porcine fetal fibroblasts induced by an inhibitor of methylation, 5-azacytidine. Cell and Tissue Research 325 445-454.

Morgan HD, Santos F, Green K, Dean W \& Reik W 2005 Epigenetic reprogramming in mammals. Human Molecular Genetics 1 R47-R58.

Mostoslavsky R, Singh N, Tenzen T, Goldmit M, Gabay C, Elizur S, Qi P, Reubinoff BE, Chess A, Cedar H et al. 2001 Asynchronous replication and allelic exclusion in the immune system. Nature 414 221-225.

Nieto M, Samper E, Fraga MF, Gonzalez de Buitrago G, Esteller M \& Serrano M 2004 The absence of p53 is critical for the induction of apoptosis by 5-aza-2'-deoxycytidine. Oncogene 23 735-743.

Nino-Soto MI, Nuber UA, Basrur PK, Ropers HH \& King WA 2005 Differences in the pattern of X-linked gene expression between fetal bovine muscle and fibroblast cultures derived from the same muscle biopsies. Cytogenetic and Genome Research 111 57-64. 
Nolen LD, Gao S, Han Z, Mann MR, Gie Chung Y, Otte AP, Bartolomei MS \& Latham KE $2005 X$ chromosome reactivation and regulation in cloned embryos. Developmental Biology 279 525-540.

Perrault SD, Hornsby PJ \& Betts DH 2005 Global gene expression response to telomerase in bovine adrenocortical cells. Biochemical and Biophysical Research Communications 335 925-936.

Peters AH, Mermoud JE, O'Carroll D, Pagani M, Schweizer D, Brockdorff N \& Jenuwein T 2002 Histone H3 lysine 9 methylation is an epigenetic imprint of facultative heterochromatin. Nature Genetics 30 77-80.

Peters AH, Kubicek S, Mechtler K, O'Sullivan RJ, Derijck AA, PerezBurgos L, Kohlmaier A, Opravil S, Tachibana M, Shinkai Y et al. 2003 Partitioning and plasticity of repressive histone methylation states in mammalian chromatin. Molecular Cell 12 1577-1589.

Plath K, Fang J, Mlynarczyk-Evans SK, Cao R, Worringer KA, Wang H, de la Cruz CC, Otte AP, Panning B \& Zhang Y 2003 Role of histone H3 lysine 27 methylation in $\mathrm{X}$ inactivation. Science 300 131-135.

Ponce de Leon FA, Li Y \& Weng Z 1992 Early and late replicative chromosomal banding patterns of Gallus domesticus. Journal of Heredity 83 36-42.

Reik W, Dean W \& Walter J 2001 Epigenetic reprogramming in mammalian development. Science 293 1089-1093.

Renaud S, Loukinov D, Abdullaev Z, Guilleret I, Bosman FT, Lobanenkov V \& Benhattar J 2007 Dual role of DNA methylation inside and outside of CTCF-binding regions in the transcriptional regulation of the telomerase hTERT gene. Nucleic Acids Research 35 1245-1256.

Santos F, Zakhartchenko V, Stojkovic M, Peters A, Jenuwein T, Wolf E, Reik W \& Dean W 2003 Epigenetic marking correlates with developmental potential in cloned bovine preimplantation embryos. Current Biology 13 1116-1121.

Sasaki T, Hansen RS \& Gartler SM 1992 Hemimethylation and hypersensitivity are early events in transcriptional reactivation of human inactive $X$-linked genes in a hamster $\mathrm{x}$ human somatic cell hybrid. Molecular Cell Biology 12 3819-3826.

Shi W, Hoeflich A, Flaswinkel H, Stojkovic M, Wolf E \& Zakhartchenko V 2003 Induction of a senescent-like phenotype does not confer the ability of bovine immortal cells to support the development of nuclear transfer embryos. Biology of Reproduction 69 301-309.
Shin KH, Kang MK, Dicterow E \& Park NH 2003 Hypermethylation of the hTERT promoter inhibits the expression of telomerase activity in normal oral fibroblasts and senescent oral keratinocytes. British Journal of Cancer 89 1473-1478.

Tamaru H \& Selker EU 2001 Histone H3 methyltransferase controls DNA methylation in Neurospora crassa. Nature 414 277-283.

Thouas GA, Korfiatis NA, French AJ, Jones GM \& Trounson AO 2001 Simplified technique for differential staining of inner cell mass and trophectoderm cells of mouse and bovine blastocysts. Reproductive Biomedicine Online 3 25-29.

Tinker AV \& Brown CJ 1998 Induction of XIST expression from the human active $X$ chromosome in mouse/human somatic cell hybrids by DNA demethylation. Nucleic Acids Research 26 2935-2940.

Vajta G 2007 Somatic cell nuclear transfer in its first and second decades: successes, setbacks, paradoxes and perspectives. Reproductive Biomedicine Online 15 582-590.

Wrenzycki C, Lucas-Hahn A, Herrmann D, Lemme E, Korsawe K \& Niemann H 2002 In vitro production and nuclear transfer affect dosage compensation of the X-linked gene transcripts G6PD, PGK, and Xist in preimplantation bovine embryos. Biology of Reproduction 66 127-134.

Xue F, Tian XC, Du F, Kubota C, Taneja M, Dinnyes A, Dai Y, Levine H, Pereira LV \& Yang X 2002 Aberrant patterns of X chromosome inactivation in bovine clones. Nature Genetics 31 216-220.

Yamada O, Takanashi M, Ujihara M \& Mizoguchi H 1998 Down-regulation of telomerase activity is an early event of cellular differentiation without apparent telomeric DNA change. Leukemia Research 22 711-717.

Yi P, Melnyk S, Pogribna M, Pogribny IP, Hine RJ \& James SJ 2000 Increase in plasma homocysteine associated with parallel increases in plasma $S$ adenosylhomocysteine and lymphocyte DNA hypomethylation. Journal of Biological Chemistry 275 29318-29323.

Received 1 October 2007

First decision 20 November 2007

Revised manuscript received 12 February 2008

Accepted 22 February 2008 